\title{
Nutritional Education: a Gap in Medical Training
}

\section{Educação Nutricional: uma Lacuna na Formação Médica}

\section{KEYWORDS}

- Medical Education.

- Nutritional Therapy.

- Curriculum.

- Education.

- Medical Schools.

- Nutrition.

Denise Bitar Vasconcelos Villacorta ${ }^{I}$ (D) Charles Alberto Villacorta de Barros ${ }^{I}$ (D) Bernardo Felipe Santana de Macedo ${ }^{I}$ (D) Milena Coelho Fernandes Caldato ${ }^{I}$ (iD

\section{ABSTRACT}

Introduction: The role of nutrition in medicine has changed from a passive function, from an adjuvant therapy, to a proactive and sophisticated therapy that prevents various health problems and changes the natural history of the disease. Recent studies show up that medical education does not sufficiently and efficiently address the patient's nutritional aspects, thus training physicians who are not confident in providing nutritional care to their patients. This study aimed to analyze and describe scientific studies that have evaluated nutrition education in medical schools, seeking within this context to find nutrition topics important for undergraduate medical education. Methods: This research was conducted through a cross-sectional, descriptive, scoping review after searching for synonyms using MeSH (Medical Subject Headings) and DeCS (Health Sciences Descriptors) tools. Results: We initially found 1.057 publications that underwent sequential screening until reaching a total of 16 articles, which achieved the scope of this research. Most articles are from the United States of America (50\%), assessed a total of 860 medical students and 243 medical schools using different approaches regarding the teaching of nutrition. Final considerations: In this review, we have shown that despite several studies ratifying the well-established association between nutrition and prevention/treatment of diseases that require outpatient care, or at the hospital level, nutrition education in undergraduate medical school has not accompanied this evidence and, for many years, the subject has been underestimated. In Brazil, no studies were found on this topic with the used descriptors. 


\section{RESUMO}

\section{PALAVRAS-CHAVE}

- Educação Médica.

-Terapia Nutricional.

- Currículo.

- Educação.

- Escolas Médicas.

- Nutrição.

Introdução: O papel da nutrição na medicina tem sido modificado de uma função passiva, de uma terapia adjuvante, para uma terapia proativa e sofisticada, que previne diversos agravos à saúde e modifica a história natural da doença. Estudos recentes observam que a educação médica não contempla, de maneira suficiente e eficiente, os aspectos nutricionais do cuidado destinado ao paciente, formando médicos pouco confiantes em promover cuidados nutricionais a seus pacientes. Este estudo teve como objetivos analisar e descrever estudos científicos que tenham avaliado a educação nutricional nas escolas médicas, buscando, neste contexto, encontrar temas em nutrição importantes para a graduação em Medicina. Método: Esta pesquisa foi realizada por meio de uma scoping review (revisão de escopo), do tipo transversal, descritiva, após pesquisa de sinônimos utilizando as ferramentas Medical Subject Headings (MeSH) e Descritores em Ciências da Saúde (DeCS). Resultados: Encontraram-se inicialmente 1.057 publicações que passaram por triagens sequenciais até chegarmos a um total de 16 artigos que alcançavam o escopo desta pesquisa. A maioria dos artigos é dos Estados Unidos (50\%) e avaliou de maneiras diferentes um total de 860 alunos de Medicina e 243 escolas médicas em relação ao ensino da nutrição. Conclusões: Nesta revisão, evidenciamos que, a despeito dos vários estudos que ratificam a relação bem estabelecida da nutrição na prevenção e no tratamento de doenças em nível ambulatorial ou hospitalar, a educação nutricional na formação médica não acompanhou essas evidências, e, por muitos anos, o assunto foi subestimado. No Brasil não foram encontrados estudos sobre esse tema com os descritores utilizados.

Received on 11/20/19

Accepted on $7 / 5 / 20$

\section{INTRODUCTION}

Human nutrition involves cultural, psychological, educational, social, political and economic aspects. Recently, with advances in food technologies and zootechnics, the food scenario has become even more complex and, without a doubt, has an impact on the health of the population ${ }^{1}$.

Several authors have reported the impact that food has on the healthdisease process ${ }^{2,3-6}$. A study published in 2016 reported atherosclerotic cardiovascular disease as the main cause of preventable death in the United States of America (USA) and that dietary factors have shown to reduce the morbidity and mortality of this type of pathology ${ }^{7}$. Other chronic pathologies, such as type 2 diabetes and high blood pressure are also strongly influenced by nutritional practices ${ }^{8}$.

Hospital malnutrition is also a critical point. Malnourished patients remain hospitalized for longer periods, suffer from impaired respiratory and cardiac functions, decreased immune function and higher rates of morbidity and mortality'.

Regarding malnourished patients admitted to the intensive care unit (ICU), for instance, there is an increase in hospital length of stay, prolonged mechanical ventilation and higher mortality rates ${ }^{10}$. However, this remains a topic that is not even part of the medical undergraduate curriculum ${ }^{1,11}$.

Nowadays, the prevalence of malnutrition in hospitals varies according to the authors, from 20 to $60 \%{ }^{12,13}$. Evidence shows that approximately $50 \%$ of patients are already experiencing some degree of malnutrition at the time of hospitalization, and at the end of the hospital length of stay, the performed nutritional assessment shows that this rate increases to $62 \%^{5,13}$.

Han et al. $(2016)^{14}$ evaluated the knowledge and perception of nutrition in resident physicians acting in primary care and showed that $86 \%$ did not feel adequately trained to discuss nutrition with patients. However, nutrition is inseparable from all other therapeutic forms, whether clinical or surgical ${ }^{15}$. In spite of that, the doctors themselves report feeling unable to promote nutritional care ${ }^{16,17}$.
Some resident physicians recognize that there is a lack of training regarding this aspect in their residency programs ${ }^{18,19}$. Devries et al. $(2017)^{18}$, in their study, found that $31 \%$ of cardiologists and $21 \%$ of cardiology residents do not remember having been taught subjects related to nutrition in their undergraduate courses, and 90\% during their residency in cardiology.

Among the factors pointed out as causes of weakness in medical training, are a very dense and extensive curriculum, the difficulty in finding specialist professors in the area and defend the inclusion of these subjects, and the lack of a consensus on which nutritional issues should be addressed ${ }^{16,20}$.

In 1977, a survey was published in which only $19 \%$ of medical schools in the United States had a course on nutrition. A study carried out in 1985 with 45 medical schools in the USA showed that $60 \%$ of schools devoted less than 20 hours to nutritional education and $20 \%$ less than 10 hours to the subject ${ }^{21}$.

Moreover, it is observed that medical schools that include some nutritional content usually do so in the first years of medical school. The lack of clinical applicability of the subject tends to make students unaware of the subject importance ${ }^{22,23}$.

This lack of training in nutritional care is evident in the hospital environment ${ }^{5,6}$. Ferreira et al. ${ }^{24}$, in 2017, assessed the knowledge of doctors from different clinics on parenteral nutritional therapy (PNT) and found that $50 \%$ of them did not feel prepared to work with parenteral nutrition. Diet is the first item of the medical prescription in the hospital and it is a complex one, because it shows variations regarding the route of administration, presentation, composition and fractioning ${ }^{25}$.

Considering that the most accepted hypothesis for this medical insecurity in prescribing the diet is the insufficient teaching of this subject in the curriculum of the undergraduate medical course, this work aims to investigate the teaching of nutrition in medical schools according to the literature. 


\section{METHODOLOGY}

This cross-sectional, descriptive study was carried out at Universidade do Estado do Pará with a convenience sample, using a scoping review, based on the search for accessible, indexed and readily available studies in the databases hosted at PubMed (US National Library of Medicine/ National Institute of Health), Eric (Education Resources Information Center), BIREME (Latin American and Caribbean Health Sciences Information Center) and Google Scholar, starting 10 years before July 31,2019 , the last day of data collection. After searching for synonyms using the MeSH (Medical Subject Headings) and DeCS (Health Sciences Descriptors) terms, the descriptors were defined. To improve the accuracy of the search for relevant articles, the following filters were applied: 10 years of publication (2009 -2019), human subjects, and English, Portuguese and Spanish languages.

As for the formulas used for the study and their respective Boolean operators, they were carried out in three different ways: :Nutrition" AND "Medical Education" OR "Medical School" AND "Curriculum" AND "Nutrition Science" AND "Nutrition Therapy", published in the last 10 years, involving human beings, written in English, Portuguese and Spanish; "Nutrition" AND "Medical Education" OR "Medical School" AND "Curriculum" AND "Nutrition Science" AND "Nutrition Therapy", with a 10-year time filter and "Nutrição" AND "Educação Médica" OR "Escolas Médicas" AND "Currículo" AND "Ciências Nutricionais" AND "Terapia Nutricional".

The articles were selected based on the pool of articles obtained with the descriptors defined by the research. Some words and/or terms were defined as excluding, as they deviate from the study objective, such as: "veterinary medicine", "early childhood education", "pre-school nutrition" and "education policy".

Studies that did not evaluate the population of interest or did not analyze at least one of the defined outcomes, were excluded from the review.
The outcomes defined for this research were:

- Focus on Medical Schools: Evaluation of nutrition teaching in medical schools;

- Focus on the student: Perception and/or evaluation of the medical student regarding nutritional education;

- Relevant topics: Topics in nutrition education most frequently recommended to be part of the medical curriculum.

\section{Statistical analysis}

The collected data were tabulated in the Microsoft Excel program spreadsheets, treated by descriptive statistical methods based on the following information collected from the studies: study design, studied sample, study site, performed interventions and reported outcomes.

\section{RESULTS}

The total number of articles found in the chosen databases comprised 1057 articles referenced up to July 31, 2019

Regarding the distribution of these manuscripts by databases, when the formula "Nutrition" AND "Medical Education" OR "Medical School" AND "Curriculum" AND "Nutrition Science" AND "Nutrition Therapy" was applied, 1012 manuscripts were collected, only from the PUBMED platform, with no findings in the others. On the other hand, when the formula "Nutrition" AND "Medical Education" OR "Medical School" AND "Curriculum" AND "Nutrition Science" AND "Nutrition Therapy" was applied, 16 studies were identified in the BIREME platform and 28 in the Google Scholar platform, totaling 44 manuscripts for this operation. Finally, when the search was carried with the formula "Nutrição" AND "Educação Médica" OR "Escolas Médicas" AND "Currículo" AND "Ciências Nutricionais" AND "Terapia Nutricional", no work was identified in any of the databases.

The synthesis of this selection can be seen in the flowchart of Figure 1.

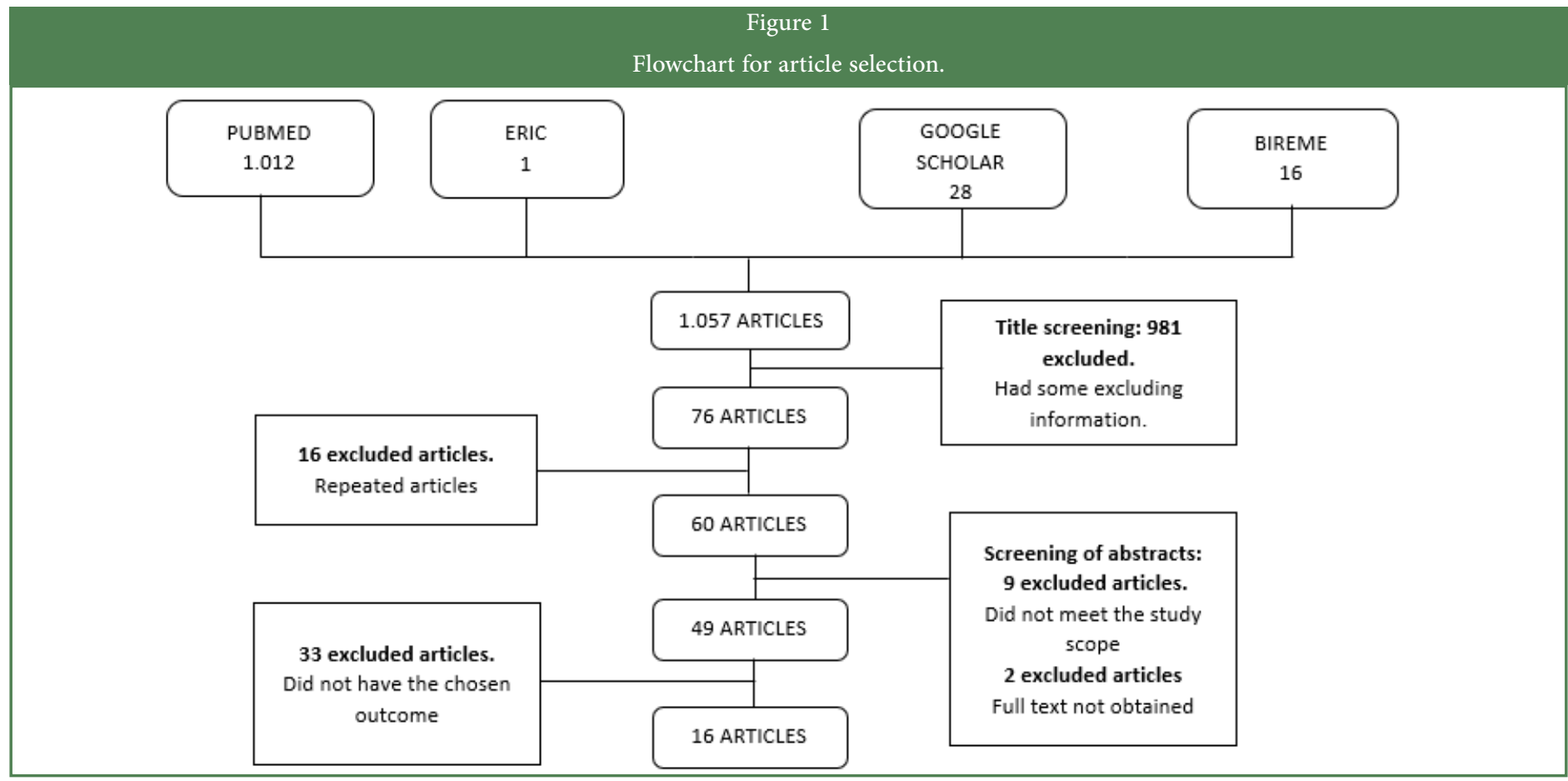

Source: Data from the present study, 2019. 


\section{Characteristics of included studies}

The search resulted in studies from 7 countries and 3 multicenter studies (1 Global, 1 European, 1 African), with $50 \%$ of the studies (8) carried out in the United States.

After the screening and reading of the full articles, they were classified according to their research design. Of the total of 16 articles, the majority, 7 (43.75\%), were cross-sectional, and the second most frequent type of study was the "before and after" study, represented by 3 articles (18.75\%) (Graphic 1).

It is noteworthy that some studies had more than one outcome. Among the outcomes defined and analyzed in the studies that were part of the research scope are:

- Outcome 1: Outcome found in $31.25 \%$ of the evaluated studies. Focus on medical schools. Of the 243 evaluated medical schools, more than $50 \%$ had less than 25 hours of nutritional training in their curriculum.

- Outcome 2: Outcome found in $50 \%$ of the evaluated studies. Focus on the Student. Of the 860 students questioned during the research of the different articles, more than half reported that they did not feel confident in handling issues related to nutrition.

- Outcome 3: Found in $43.75 \%$ of the evaluated studies. Relevant topics: Of the most frequently suggested topics for inclusion in medical education, there were three main groups:

1. Topics on basic nutritional sciences, such as the study of macro and micronutrients, energy expenditure, nutritional assessment and nutritional risk;

2. Topics on nutritional guidelines applied to chronic diseases such as cardiovascular diseases, obesity, hypertension, diabetes and cancer.

3. Topics on nutritional support for hospitalized patients, including enteral and parenteral nutrition.

\section{Synthesis of studies}

The selection of the 16 articles used in this research, with their main characteristics, is shown in Table 1.

\section{DISCUSSION}

The role of nutrition in medicine has changed from a passive function to a proactive and complex therapy, which prevents numerous health problems and has changed the natural history of the disease $\mathrm{e}^{30}$. Even so, the most prevalent causes of morbidity and mortality in developed and developing countries are directly or indirectly related to the $\operatorname{diet}^{2}$.

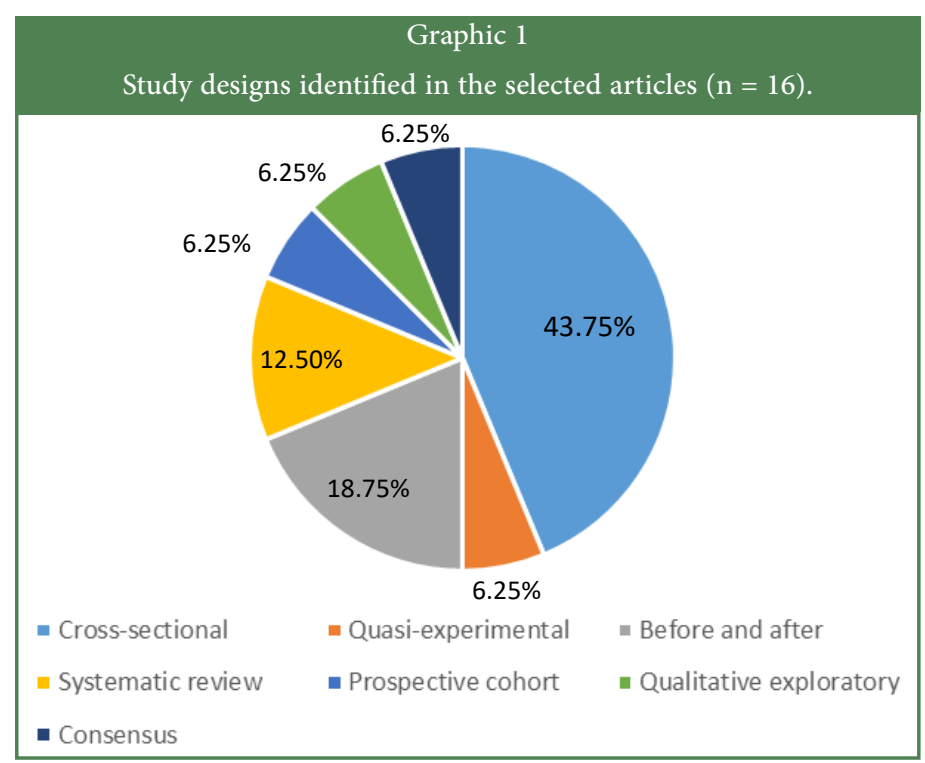

Source: Data from the present study, 2019.

\begin{tabular}{|c|c|c|c|c|c|c|}
\hline \multicolumn{7}{|c|}{$\begin{array}{c}\text { Table } 1 \\
\text { Synthesis of selected studies. }\end{array}$} \\
\hline $\begin{array}{l}\text { Author / Year / Study } \\
\text { Location }\end{array}$ & Sample & Type of study & Intervention & $\begin{array}{l}\text { Outcome } 1 \text { - Nutrition in } \\
\text { medical schools }\end{array}$ & $\begin{array}{c}\text { Outcome } 2 \text { - Focus on } \\
\text { the Student }\end{array}$ & $\begin{array}{c}\text { Outcome } 3 \text { - Relevant } \\
\text { topics }\end{array}$ \\
\hline $\begin{array}{l}\text { Adams, KM et al., } 2010 \\
\text { (United States) }^{22}\end{array}$ & $\begin{array}{l}109 \text { medical } \\
\text { schools }\end{array}$ & $\begin{array}{c}\text { Cross- } \\
\text { sectional }\end{array}$ & NA & $\begin{array}{l}\text { Mean hours of nutritional } \\
\text { education: } 19.6 \mathrm{~h} .27 \% \text { ( } 28 / 105) \\
\text { of medical schools provided } \\
\text { a minimum of } 25 \text { hours. } 30 \\
\text { schools have } 12 \text { hours or less of } \\
\text { nutritional instruction }\end{array}$ & NA & NA \\
\hline $\begin{array}{l}\text { Walsh CO et al., } 2011 \\
\text { (United States) }^{15}\end{array}$ & $\begin{array}{l}125 \text { medical } \\
\text { students }\end{array}$ & $\begin{array}{l}\text { Quasi } \\
\text { Experi- } \\
\text { mental }\end{array}$ & $\begin{array}{l}\text { Dedicated x integrated } \\
\text { nutritional curriculum. } \\
\text { Course dedicated to nutrition } \\
\text { with } 28 \mathrm{~h} \text {, with } 14 \mathrm{~h} \text { a week, } 45 \\
\text { min of class, } 90 \text { min of activity } \\
\text { x Introduction to clinical } \\
\text { nutrition with some classes } \\
\text { and activities, with other } \\
\text { subjects included in the study } \\
\text { of organs and systems. }\end{array}$ & NA & $\begin{array}{l}\text { Although students } \\
\text { prefer the course } \\
\text { dedicated to nutrition, } \\
\text { the students acquired } \\
\text { similar clinical } \\
\text { nutrition skills with } \\
\text { both methodologies }\end{array}$ & $\begin{array}{l}\text { Macro/Micronutrients, } \\
\text { obesity, evaluation, } \\
\text { nutritional counseling, } \\
\text { among others. }\end{array}$ \\
\hline
\end{tabular}




\begin{tabular}{|c|c|c|c|c|c|c|}
\hline \multicolumn{7}{|c|}{ Continuation. } \\
\hline $\begin{array}{c}\text { Author / Year / Study } \\
\text { Location }\end{array}$ & Sample & Type of study & Intervention & $\begin{array}{c}\text { Outcome } 1 \text { - Nutrition in } \\
\text { medical schools }\end{array}$ & $\begin{array}{c}\text { Outcome } 2 \text { - Focus on } \\
\text { the Student }\end{array}$ & $\begin{array}{c}\text { Outcome } 3 \text { - Relevant } \\
\text { topics }\end{array}$ \\
\hline $\begin{array}{l}\text { Afaghi, A et al., } 2012 \\
\qquad(\text { Iran })^{42}\end{array}$ & $\begin{array}{l}46 \text { medical } \\
\text { students }\end{array}$ & $\begin{array}{l}\text { Before and } \\
\text { after }\end{array}$ & $\begin{array}{l}\text { Eight extra hours in a diet } \\
\text { therapy workshop followed } \\
\text { by case discussions from the } \\
\text { fourth to the seventh year of } \\
\text { the course. }\end{array}$ & NA & $\begin{array}{l}\text { There was an increase in } \\
\text { nutritional knowledge } \\
\text { in the pre-test from } 20 \\
\text { to } 70 \% \text { in the post-test. } \\
\text { Gain knowledge after } \\
\text { the course. }\end{array}$ & $\begin{array}{l}\text { Nutrition in chronic } \\
\text { diseases and intake } \\
\text { assessment and weight } \\
\text { management }\end{array}$ \\
\hline $\begin{array}{l}\text { Schlair, S et al., } 2012 \\
\text { (United States) }^{41}\end{array}$ & $\begin{array}{l}162 \text { medical } \\
\text { students }\end{array}$ & $\begin{array}{l}\text { Before and } \\
\text { after }\end{array}$ & 2-week Nutrition Course & NA & $\begin{array}{l}\text { Improvement in } \\
\text { dietary counseling, } \\
\text { confidence in guiding } \\
\text { and evaluating the } \\
\text { diet, attitude regarding } \\
\text { nutritional therapy }\end{array}$ & $\begin{array}{l}\text { Chronic diseases; } \\
\text { obesity, nutritional } \\
\text { advice and dietary } \\
\text { knowledge }\end{array}$ \\
\hline $\begin{array}{c}\text { Orimo, } \mathrm{H} \text { et al., } 2013 \\
{\text { (Japan })^{26}}^{2}\end{array}$ & $\begin{array}{l}67 \text { Medical } \\
\text { Schools }\end{array}$ & $\begin{array}{l}\text { Cross- } \\
\text { sectional }\end{array}$ & NA & $\begin{array}{l}37 \% \text { offer courses dedicated to } \\
\text { nutrition and clinical nutrition } \\
\text { (isolated or integrated). } \\
\text { 11h-duration and } 5 \text { h substantial } \\
\text { nutrition content }\end{array}$ & NA & NA \\
\hline $\begin{array}{l}\text { Crowley, J et al., } 2014 \\
\text { (N. Zeland })^{43}\end{array}$ & $\begin{array}{l}72 \text { Medical } \\
\text { students }\end{array}$ & $\begin{array}{l}\text { Before and } \\
\text { after }\end{array}$ & $\begin{array}{c}\text { 12-week course; } 13 \text { hours of } \\
\text { nutritional content }\end{array}$ & NA & $\begin{array}{l}\text { The students can } \\
\text { reflect on their own } \\
\text { nutritional behavior } \\
\text { after taking a course } \\
\text { that includes this } \\
\text { content in the } \\
\text { early stages of their } \\
\text { undergraduate training }\end{array}$ & NA \\
\hline $\begin{array}{c}\text { Kris-Etherton, PM } \\
\text { et al., } 2014 \text { (United } \\
\text { States) }\end{array}$ & NA & $\begin{array}{l}\text { Systematic } \\
\text { review }\end{array}$ & NA & NA & NA & $\begin{array}{l}\text { Tables with subjects } \\
\text { on nutrition to be } \\
\text { included in the medical } \\
\text { curriculum }\end{array}$ \\
\hline $\begin{array}{l}\text { Kushner, RF et al., } 2014 \\
\text { (United States) }^{47}\end{array}$ & NA & $\begin{array}{l}\text { Systematic } \\
\text { review }\end{array}$ & NA & NA & NA & $\begin{array}{l}\text { Proposed subjects in } \\
\text { nutrition to be taught } \\
\text { in the first } 4 \text { years of } \\
\text { the course }\end{array}$ \\
\hline $\begin{array}{l}\text { Sodjinou, R et al., } 2014 \\
\text { (Western Africa) }^{27}\end{array}$ & $\begin{array}{l}11 \text { Medical } \\
\text { schools }\end{array}$ & $\begin{array}{l}\text { Cross- } \\
\text { sectional }\end{array}$ & NA & $\begin{array}{l}56.9 \mathrm{~h} \text { of contact with nutrition in } \\
\text { the course, with } 67 \% \text { dedicated } \\
\text { to clinical nutrition. Integrated } \\
\text { nutrition education in } 46 \% \text {. } \\
\text { Traditional methodology was } \\
\text { applied in all of them }\end{array}$ & NA & $\begin{array}{c}\text { Table with subjects } \\
\text { on nutrition to be } \\
\text { included in the medical } \\
\text { curriculum }\end{array}$ \\
\hline $\begin{array}{c}\text { Frantz, D et al., } \\
2016 \text { (United States) }^{46}\end{array}$ & $\begin{array}{l}122 \text { Medical } \\
\text { students }\end{array}$ & $\begin{array}{l}\text { Cross- } \\
\text { sectional }\end{array}$ & NA & NA & $\begin{array}{l}29 \% \text { of students think } \\
\text { clinical nutrition is } \\
\text { sufficient in the medical } \\
\text { course. Contact with } \\
\text { clinical nutrition of } \\
2.8 \text { h weekly, on average. } \\
\text { Four or more weeks } \\
\text { are associated with } \\
\text { greater confidence } \\
\text { in the management } \\
\text { of clinical nutrition. } \\
\text { Difficulty in initiating } \\
\text { clinical nutrition } \\
\text { with pharmacological } \\
\text { therapy }\end{array}$ & NA \\
\hline
\end{tabular}




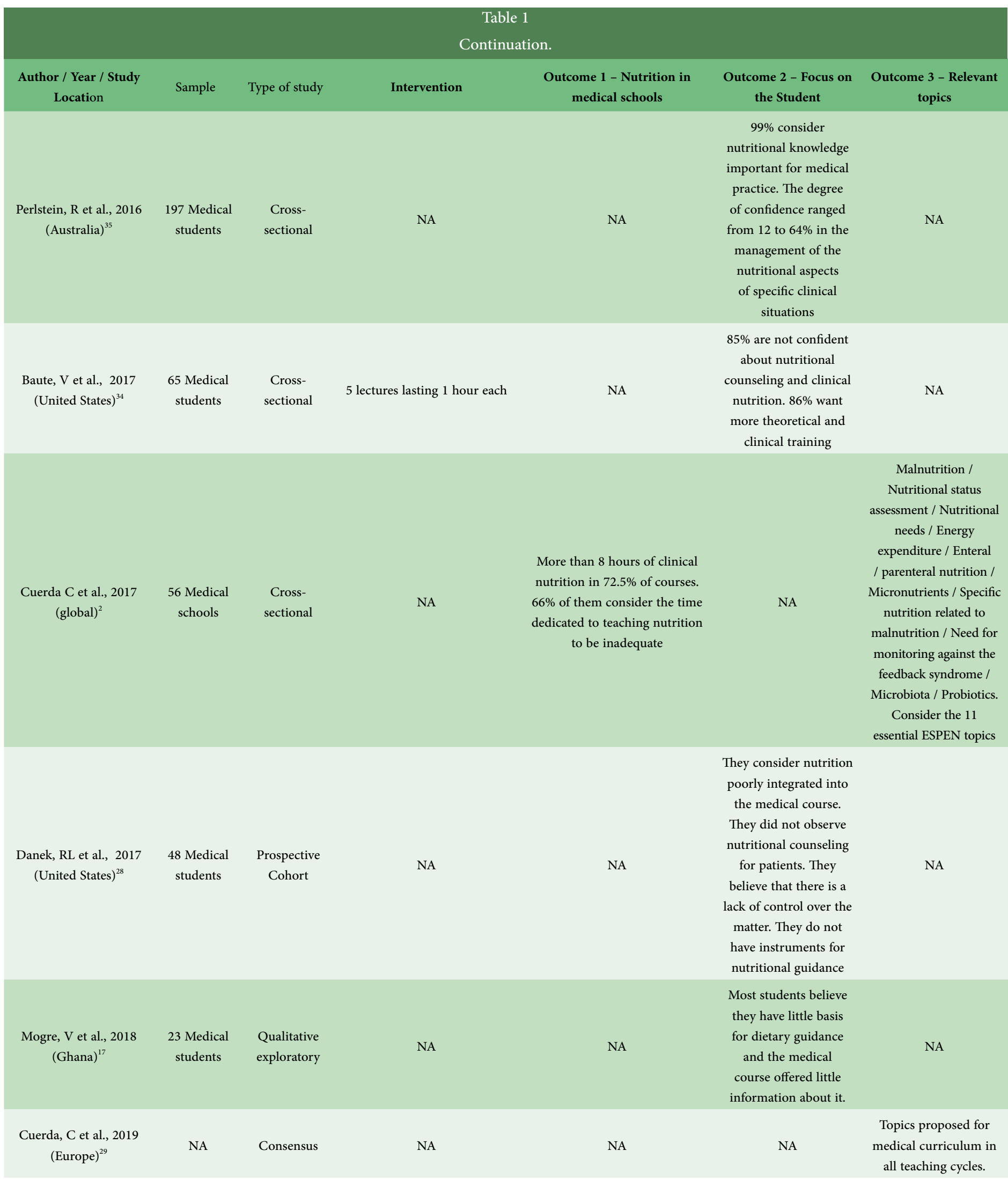

Source: Data from the present study, 2019

NA: not applicable 
In the hospital environment, the problem is a latent one. A national study, involving 4,000 patients and published in 2001, showed a hospital malnutrition rate of $48 \%$. After more than 15 years, a meta-analysis published in 2017, with a sample of 29,474 patients from 12 countries in Latin America, including 57.7\% Brazilian patients, showed an even higher hospital malnutrition rate of up to $60 \%{ }^{31,32}$.

Mass education is understood as the best way to modify the nutritional habits that occur with the disease process. This fact is clear in Law $\mathrm{n}$. $13.666 / 2018$, which makes food and nutrition education mandatory in the school curricula of elementary and high school students from public and private education institutions throughout Brazil ${ }^{33}$.

Paradoxically, there are no regulations regarding how much nutritional knowledge a doctor in training has to obtain for it to become a modifying agent of this reality. And the lack of studies published in Brazil on nutritional education in medical schools suggests that the discussion regarding this fragility has not even started. A recent, randomized and controlled study demonstrated the potential positive impact on patients who participated in a nutritional education course taught by medical students ${ }^{34}$.

Despite the growing importance of the nutritional aspects in the therapeutic management of the patient, and the fact that the physician is in the front line to raise awareness about healthier eating habits, this competence has not been attained by schools that train medical professionals around the world, so much that a global study led by ESPEN (European Society for Clinical Nutrition and Metabolism), with representation from 57 countries, demonstrated that nutritional education in medical courses is heterogeneous and insufficient ${ }^{2,11}$.

A study carried out in Australia with medical students found that 99\% of the students considered nutritional education important and the degree of confidence they mentioned in managing nutritional care ranged between 12 and $64^{35}$.

The concern with nutritional education in schools is not a recent phenomenon outside Brazil. In 1985, the National Academy of Sciences (NAS), through its Committee on Nutrition in Medical Education, presented to society the work entitled 'Nutrition Education in US Medical Schools', considered a milestone in medical literature on this topic ${ }^{36}$.

Driven by this study, the Nutrition Academic Award (NAA) was launched, which promoted the integration of nutritional content in the medical curriculum and produced guidelines on how to achieve this integration. However, in 2005, resources for this program were suspended, limiting its impact to only 21 American medical schools. After 3 decades of the national assessment organized by the NAS, nutrition in medical schools is still an issue to be resolved ${ }^{21}$.

The relevance of the topic for the American public health is clear when one considers that the main health problems in North Americans are obesity, cardiovascular diseases, diabetes and cancer, which are directly related to dietary factors and lifestyle habits and, therefore, potentially preventable?

While international authors have been discussing the deficiency in nutritional education in medical schools and residency programs for over 30 years, proposing specific actions and conferences for this topic ${ }^{37}$, no studies were found that were carried out in Brazil among the researched literature using the descriptor formula. This is a matter of concern, since in Brazil, recent surveys have shown that more than $50 \%$ of the population is overweight and that the prevalence of hospital malnutrition can affect up to $60 \%$ of hospitalized patients ${ }^{38,39}$.

Quaresma et $\mathrm{al}^{40}$, in 2019, evaluated on-duty doctors at an intensive care unit in a public hospital in Brazil and found that $65 \%$ of the respondents have difficulty recognizing patients at nutritional risk.

Among the described barriers for advancing the teaching of nutrition in medical schools are the low clinical applicability, the perception that nutritional care is not the doctor's responsibility, lack of knowledge of the medical school in clinical nutrition, lack of motivation by professors in teaching the subject, and an overcrowded curriculum, among others ${ }^{17}$.

In the last decade (2009-2019), the focus of this research, it was identified that the majority (43.75\%) of the selected studies were crosssectional ones. This suggests that medical education managers seek to increase the discussion on the topic, initially working to define a situational diagnosis and thus lead the process to more vigorous actions.

Other studies were of the 'before and after' type, 18.75\%, having as interventions courses dedicated to clinical nutrition that were not part of the regular medical undergraduate curriculum. It is perfectly understandable that a curricular change is not a simple task to achieve, since more advanced classes, for instance, would not benefit from the curricular insertions only in the first semesters of the course.

Although old, the minimum recommendation of 25 hours of nutrition education in the medical curriculum is the starting point and the reference for most interventions. Nutrition courses have been described in the following formats: only 5 lectures; others with a workload of 13 hours; 2 weeks in length and also those that are included for 3 years in the undergraduate clinical cycle $\mathrm{e}^{34,41-43}$.

Regarding the population evaluated in each selected study, two different populations were found: the medical school and the student. The medical schools were evaluated through questionnaires sent to the institutions' coordinators and managers, a fact that may constitute a selection bias, since the person responsible for answering the form was the one with the most interest in offering a more "adequate" picture than the actual reality.

Of the 243 schools evaluated in the several added studies, in 40 of them it was not possible to identify how many hours of nutritional education were administered. Among those of which workload was possible to be evaluated, more than $50 \%$ offered less than the minimum of 25 hours recommended by the National Academy of Sciences ${ }^{36}$, ranging from 4.2 to 19.6 hours. When one considers that a medical course has a minimum workload of 7,200 hours, it is evident that the time for the teaching of nutrition is negligible.

The National Curricular Guidelines (NCG) of the medical course, published in 2014, practically do not contain any line on the nutritional care of the patient. In subsection I, which deals with the Attention to Individual Health Needs, Article 13, which comments on therapeutic plans, mentions as one of its objectives the "establishment, based on clinical-epidemiological reasoning in specific contexts, of therapeutic plans contemplating the dimensions of promotion, prevention, treatment and rehabilitation". In this context, planning the therapeutic intervention means being prepared for all items such as dietary care, as it can constitute both prevention and treatment of some pathologies ${ }^{4}$.

Recently, Neumann et al (2019) ${ }^{45}$ adapted and improved the competencies for medical internship students to the Portuguese language,

REVISTA BRASILEIRA DE EDUCAÇÃO MÉDICA

7 44 (4) : e107; 2020 
based on the assessment of 15 EPAs (Entrustable Professional Activities). We highlight 2 EPAs that are strongly related to nutritional education: To collaborate as a member of a multiprofessional team, and; educating patients: disease management, health promotion and preventive medicine.

The medical student's assessment was similar to that of medical schools, using questionnaires of perception and, sometimes, of knowledge; the students were selected and assessed by researchers from their own educational institution, favoring evaluation bias.

Of the 860 students questioned in the selected studies, more than half reported not feeling prepared to handle patient nutritional care. Frantz et al. (2016) ${ }^{46}$ performed a survey of 122 medical school internship students, where $71 \%$ reported feeling inadequately prepared to practice clinical nutrition.

In an attempt to solve this deficiency, some courses introduced nutrition based on basic topics, such as the study of macro and micronutrients, energy expenditure and nutritional needs in the first two years of the course, called pre-clinics ${ }^{42}$. However, with the emergence of evidence that chronic diseases such as cardiovascular diseases, diabetes, hypertension and cancer are directly influenced by diet, and that, therefore, medical treatment was necessary to treat them, the subject started to be included in the first four years of the medical course, with a more clinical focus in the third and fourth years, seeking to develop skills in nutritional management of patients and using problem-based learning methods ${ }^{47}$.

In this study, $50 \%$ of the articles presented outcome n. 3 , related to the most frequently mentioned topics and considered more relevant to be part of the medical curriculum. The subjects were congregated in three groups.

The topics of basic nutrition were mentioned by all articles, since this knowledge is essential for the understanding of the pathophysiology of nutritional disorders, thus making clinical applicability feasible. Among them, the knowledge about macro and micronutrients, nutritional needs, nutritional assessment and energy expenditure stands out. Data from VIGITEL/Ministry of Health published in 2017 showed that only $24.9 \%$ to $49.8 \%$ of Brazilians regularly consume fruits and vegetables, information that suggests the population's inadequate awareness of the main healthy sources of macro and micronutrients ${ }^{48}$.

The nutritional management of chronic diseases influenced by the diet was also frequently mentioned. The examples include cardiovascular diseases, which constitute one of the main causes of death worldwide; hypertension, directly related to the consumption of salt and processed foods; diabetes, which has as its main support an adequate consumption of carbohydrates; some types of cancer, which can be triggered by oncogenic factors present in food; and finally, obesity, which is directly influenced by the population's dietary pattern ${ }^{17,49,50}$.

Finally, a topic that took on greater proportions in the 1970s, when the first publications on hospital malnutrition appeared, and continues to rise to the present day, was nutritional therapy for hospitalized patients. This topic deserves to be highlighted, as it involves the care of patients in borderline pathological situations. And unlike other practice environments, the physician is the trigger for nutritional care through its indication and prescription. It requires specific knowledge, considering the types of nutritional therapies, such as enteral and parenteral nutrition, which in addition to significantly higher costs to the hospital, are permeated by greater risks and possible complications during its implementation process.

Aiming to regulate the use of this type of therapy, norms were created in Brazil by the Ministry of Health that regulate the entire process of using enteral and parenteral nutrition, from its indication to its administration, going through quality controls, transportation and handling ${ }^{51,52}$.

\section{FINAL CONSIDERATIONS}

In this scope review, we show that despite the several studies endorsing the well-established association of nutrition, both in the prevention and treatment of chronic diseases that require outpatient care, as in pathologies that depend on therapies at the hospital level, nutritional education in medical training has not followed this evidence and, for many years, the subject has been underestimated. Currently, it has been increasingly discussed outside Brazil.

The absence of Brazilian research in this area makes it possible to develop new studies aiming to diagnose the national reality and later search for strategies consistent with the identified context. At the moment, as in other countries, extracurricular courses can be an alternative to provide the knowledge and skills that are not being delivered by medical schools.

\section{REFERENCES}

1. Godoy A, Lopes D, Garcia R. Transformações socioculturais da alimentação hospitalar. Hist Ciênc Saúde-Manguinhos. 2007;14(4):1197-215.

2. Cuerda C, Schneider S, Van Gossum A. Clinical nutrition education in medical schools: results of an Espen survey. Clin Nutr. 2017;36(4):915-6.

3. Pôrto PA, Mendonça SS. Conhecimento dos profissionais de enfermagem e médicos de um hospital público sobre terapia nutricional. Rev Bras Nutr Clín. 2015;30(3):227-34.

4. Cunha HF, Rocha EEM, Hissa M. Práticas em terapia nutricional entre médicos: inquérito via internet. Rev. Bras Nutr Clín. 2014;29(4):335-41.

5. Massimi M. Alimentos, palavras e saúde (da alma e do corpo), em sermões de pregadores brasileiros do século XVII. Hist Ciênc SaúdeManguinhos. 2006;13(2):253-70.

6. Raman M, Violato C, Coderre S. How much do gastroenterology fellows know about nutrition? J Clin Gastroenterol. 2009;43(6):559-64.

7. Crawford AL, Aspry KE. Teaching doctors-in-training about nutrition: where are we going in 2016? R I Med J. 2016;99:23-5.

8. Kris-Etherton P, Akabas S, Douglas P, Kohlmeier M, Laur C, Lenders $\mathrm{C}$, et al. Nutrition competencies in health professionals' education and training: a new paradigm. Adv Nutr. 2015;6(1):83-7.

9. Hark L, Deen D. Position of the Academy of Nutrition and Dietetics: interprofessional education in nutrition as an essential component of medical education. Journal of the Academy of Nutrition and Dietetics. 2017;117(7):1104-13.

10. Castro M, Pompilio C, Horie L, Verotti C, Waitzberg D. Education program on medical nutrition and length of stay of critically ill patients. Clin Nutr. 2013;32(6):1061-66.

11. Kris-Etherton P, Akabas S, Bales C, Bistrian B, Braun L, Edwards $M$, et al. The need to advance nutrition education in the training of health care professionals and recommended research to 
evaluate implementation and effectiveness. Am J Clin Nutr. 2014;99(5):1153S-1166S.

12. Borghi R, Meale MM, Gouveia MAP, França JID, Damião AOMC. Perfil nutricional de pacientes internados no Brasil: análise de 19.222 pacientes (Estudo BRAINS). Rev Bras Nutr Clín. 2013;28(4):255-63.

13. Bottoni A, Hassan DZ, Nacarato A, Garnes SA, Bottoni A. Porque se preocupar com a desnutrição hospitalar?: revisão de literatura. J Health Sci Inst. 2014;32(3):314-7.

14. Han S, Auer R, Cornuz J, Marques-Vidal P. Clinical nutrition in primary care: an evaluation of resident physicians' attitudes and selfperceived proficiency. Clin Nutr ESPEN. 2016;15:69-74.

15. Walsh C, Ziniel S, Delichatsios H, Ludwig D. Nutrition attitudes and knowledge in medical students after completion of an integrated nutrition curriculum compared to a dedicated nutrition curriculum: a quasi-experimental study. BMC Med Educ. 2011;11(1): 1-7.

16. Ray S, Ball L, Crowley J, Laur C, Rajput-Ray M, Gillam S. Nutrition in medical education: reflections from an initiative at the University of Cambridge. Journal of Multidisciplinary Healthcare. 2014;7:209-215.

17. Mogre V, Stevens F, Aryee P, Amalba A, Scherpbier A. Why nutrition education is inadequate in the medical curriculum: a qualitative study of students' perspectives on barriers and strategies. BMC Med Educ. 2018;18(1): 1-11.

18. Devries S, Agatston A, Aggarwal M, Aspry K, Esselstyn C, KrisEtherton $\mathrm{P}$, et al. A deficiency of nutrition education and practice in cardiology. Am J Med. 2017;130(11):1298-305.

19. Singh H, Duerksen D. Survey of clinical nutrition practices of Canadian gastroenterologists. Can J Gastroenterol. 2006;20(8):527-30.

20. Ball L, Barnes K, Laur C, Crowley J, Ray S. Setting priorities for research in medical nutrition education: an international approach. BMJ Open. 2016;6(12):e013241.

21. Sacks G. The shrinking of formalized nutrition education in health professions curricula and postgraduate training. JPEN J Parenter Enteral Nutr. 2017;41(2):217-25.

22. Adams K, Kohlmeier M, Zeisel S. Nutrition education in U.S. medical schools: latest update of a national survey. Acad Med. 2010;85(9):1537-42.

23. Kiraly L, McClave S, Neel D, Evans D, Martindale R, Hurt R. Physician nutrition education. Nutrition in Clinical Practice. 2014;29(3):332-7.

24. Ferreira HCC, Rodrigues PA. Avaliação do conhecimento médico sobre terapia nutricional parenteral em um hospital público do Distrito Federal. BRASPEN J. 2017;32(4):387-393.

25. Pazin-Filho A, Frezza G, Matsuno A, Alcântara S, Cassiolato S, Bitar J, et al. Princípios de prescrição médica hospitalar para estudantes de medicina. Medicina (Ribeirao Preto, Online). 2013;46(1):183-194.

26. Orimo $\mathrm{H}$, Ueno $\mathrm{T}$, Yoshida $\mathrm{H}$, Sone $\mathrm{H}$, Tnaka A, Itakura $\mathrm{H}$. Nutrition education in japanese medical schools: a follow-up survey. Asia Pac J Clin Nutr. 2013;22(1):144-149

27. Sodjinou R, Bosu WK, Fanou N, Déart L, Kupka R, Tchibindat F et al. Nutrition training in medical and other health professional schools in West Africa: the need to improve current approaches and enhance training effectiveness. Golb Health Action. 2014;7:24827-35

28. Danek RL, Berlin KL, Waite GN, Geib RW. Perceptions of nutrition education in the current medical school curriculum. Fam Med. 2017;49(10):803-806
29. Cuerda C, Muscaritoli M, Donini LM, Schneider S, Vargas JA, Gossum AV et al. Nutrition education in medical schools (NEMS). An ESPEN position paper. Clin Nutr. 2019;38(3):969-974

30. Spear S, Sim V, Moore F, Todd S. Just say no to intensive care unit starvation. Nutrition in Clinical Practice. 2013;28(3):387-91.

31. Waitzberg DL1, Caiaffa WT, Correia MI. Hospital malnutrition: the Brazilian national survey (IBRANUTRI): a study of 4000 patients. Nutrition. 2001 Jul-Aug;17(7-8):573-80.

32. Toledo DO, Piovacari SMF, Horie LM, Matos LBN, Castro MG, Ceniccola GD, et al. Campanha "Diga não à desnutrição": 11 passos importantes para combater a desnutrição hospitalar. Braspen J. 2018;33(1):86-100.

33. Agência Senado. Sancionada lei que obriga escolas a incluir educação alimentar e nutricional no currículo acadêmico. Brasília, 2019 [acesso 20 ago 2019]. Available from: https://www12.senado.leg. br/noticias/audios/2018/05/sancionada-lei-que-obriga-escolas-aincluir-educacao-alimentar-e-nutricional-no-curriculo-academico.

34. Baute V, Carr A, Blackwell J, Carstensen E, Chhabra P, Porter, L et al. Incorporating formal nutrition education into a medical school curriculum: a student-initiated lecture series. The Am J Med. 2017;130(6):623-5.

35. Perlstein R, McCoombe S, Shaw C, Nowson C. Medical students' perceptions regarding the importance of nutritional knowledge and their confidence in providing competent nutrition practice. Public Health. 2016;140:27-34.

36. United States of America. National Research Council (US) Committee on Nutrition in Medical Education. Nutrition Education in U.S. Medical Schools. Washington, DC: National Academy Press; 1985.

37. Laur C, Ball L, Ahankari A, Avdagovska M, Crowley J, Deen D, et al. Proceedings of the inaugural International Summit for Medical Nutrition Education and Research. Public Health. 2016;140:59-67.

38. Associação Brasileira para Estudo da Obesidade e da Síndrome Metabólica. 2019 [acess 14 jun 2019]. Available from: http://www. abeso.org.br/atitude-saudavel/mapa- obesidade.

39. Correia MITD, Perman MI, Waitzberg DL. Hospital malnutrition in Latin America: a systematic review. Clin Nutr (Edinb.). 2017;36( 4):958-67.

40. Quaresma EM, Villacorta DBV, Silva RA, Veríssimo AOL, Caldato MCF. Análise de compreensão a respeito da terapia nutricional em unidades de terapia intensiva de um hospital escola. Revista Eletrônica Acervo Saúde. 2019;9(3):1112-7.

41. Schlair S, Hanley K, Gillespie C, Disney L, Kalet A, Darby P, et al. How medical students' behaviors and attitudes affect the impact of a brief curriculum on nutrition counseling. J Nutr Educ Behav. 2012;44(6):653-7.

42. Afaghi A, Haj Agha Mohamadi A, Ziaee A, Sarchami R. Effect of an integrated case-based nutrition curriculum on medical education at Qazvin University of Medical Sciences, Iran. Global Journal of Health Science. 2011;4(1):112-117.

43. Crowley J, Ball L, Leveritt MD, Arroll B, Han DY, Wall C. Impact of an undergraduate course on medical students' self-perceived nutrition intake and self-efficacy to improve their health behaviours and counselling practices. J Prim Health Care. 2014 Jun 1;6(2):101-7.

44. Brasil. Ministério da Educação. Diretrizes Curriculares Nacionais

REVISTA BRASILEIRA DE EDUCAÇÃO MÉDICA

$94(4): \mathrm{e} 107 ; 2020$ 
do Curso de Graduação em Medicina. Brasília; 2014 [Access in 22 jul 2019]. Available from: http://portal.mec.gov.br/index. php?option $=$ com_docman $\&$ view $=$ download $\&$ alias $=15874$-rces00314\&category_slug=junho-2014-pdf\&Itemid=30192.

45. Neumann C, Gerbase M, Blank D, Capp E, Oliveira M. Avaliação de competências no internato: atividades profissionais confiabilizadoras essenciais para a prática médica. Porto Alegre: UFCSPA, UFRGS; 2019.

46. Frantz D, McClave S, Hurt R, Miller K, Martindale R. Cross-sectional study of U.S. interns' perceptions of clinical nutrition education. JPEN J Parenter Enteral Nutr. 2015;40(4):529-35.

47. Kushner R, Van Horn L, Rock C, Edwards M, Bales C, Kohlmeier M, et al. Nutrition education in medical school: a time of opportunity. Am J Clin Nutr. 2014;99(5):1167S-1173S.

48. Brasil. Ministério da Saúde. Secretaria de Vigilância em Saúde. Departamento de Vigilância de Doenças e Agravos nas Transmissíveis e Promoção de Saúde. Vigitel Brasil 2016: vigilância de fatores de risco e proteção para doenças crônicas por inquérito telefônico: estimativas sobre frequência e distribuição sociodemográfica de fatores de risco e proteção para doenças crônicas nas capitais dos 26 estados brasileiros e no Distrito Federal em 2016. Brasília: Ministério da Saúde; 2017.

49. Bastos L. OPAS/OMS Brasil - Doenças cardiovasculares. Pan American Health Organization, World Health Organization; 2019 [Access in 15 jun 2019]. Available from: https://www.paho.org/bra/ index.php?option $=$ com_content $\&$ view $=$ article\&id=5253: doencascardiovasculares\&Itemid $=1096$

50. Instituto Nacional do Câncer. Ministério da Saúde; 2019. [Acess in 28 July 2019] Available from: https://www.inca.gov.br/mitos-e- verdades/alimentacao.

51. Brasil. Resolução da Diretoria Colegiada no 63, 2000. Brasília; 2000. [Acess in 15 July 2019] Available from: https://www20.anvisa.gov. br/segurancadopaciente/index.php/legislacao/item/resolucao-dadiretoria-colegiada-rcd-n-63-de-6-de-julho-de-2000.

52. Brasil. Portaria $n^{\circ} 272$, 1998. Brasília; 1998. [Acess in 10 July 2019] Available from: http://bvsms.saude.gov.br/bvs/saudelegis/svs1/1998/ prt0272_08_04_1998.html.

\section{AUTHORS 'CONTRIBUTION}

Denise Bitar Vasconcelos Villacorta: database search, collection of results, writing of the manuscript, review of the obtained results and overall review of the manuscript. Charles Alberto Villacorta de Barros: database search, collection of results, writing of the manuscript, review of the obtained results and overall review of the manuscript. Bernardo Felipe Santana de Macedo: textual review, graph formatting and finalization for publication. Milena Coelho Fernandes Caldato: advice regarding the topic, collection of results and periodic review of the article progression.

\section{CONFLICTS OF INTEREST}

The authors declare no conflicts of interest.

\section{ADDRESS FOR CORRESPONDENCE}

Denise Bitar Vasconcelos Villacorta. Rua Domingos Marreiros, 907, ap. 1402, Umarizal, Belém, PA, Brasil. CEP: 66055-215.

E-mail: denibvv@gmail.com 